\title{
Selection Wind Farm Sites Based on GIS Using a Boolean Method: Evaluation of the Case of Cameroon
}

\author{
Fotsing Metegam Isabelle Flora ${ }^{1,2 *}$, Njomo Donatien1, René Tchinda ${ }^{2}$, \\ Oumarou Hamandjoda ${ }^{3}$
}

${ }^{1}$ Environmental Energy Technologies Laboratory (EETL), University of Yaounde 1, Yaounde, Cameroon

${ }^{2}$ Laboratory of Industrial Systems and Environment of the University of Dschang, Dschang, Cameroon

${ }^{3}$ Energetic Laboratory, National Higher Polytechnic School, Yaounde, Cameroon

Email: ^fotsing85@yahoo.fr

How to cite this paper: Flora, F.M.I., Donatien, N., Tchinda, R. and Hamandjoda, O. (2021) Selection Wind Farm Sites Based on GIS Using a Boolean Method: Evaluation of the Case of Cameroon. Journal of Power and Energy Engineering, 9, 1-24. https://doi.org/10.4236/jpee.2021.91001

Received: August 21, 2020

Accepted: January 23, 2021

Published: January 26, 2021

Copyright ( 2021 by author(s) and Scientific Research Publishing Inc. This work is licensed under the Creative Commons Attribution International License (CC BY 4.0).

http://creativecommons.org/licenses/by/4.0/ (c) (i) Open Access

\begin{abstract}
The negative effects of traditional methods of electricity generation on the environment have created the need for strategic planning and development of renewable and sustainable energy systems. This paper presents the analysis of the suitability of wind farm sites using a Boolean decision-making approach based on geographic information system (GIS) modeling. This analysis is based on different climatic, geographical, economic and environmental criteria such as wind resource, slope, accessibility by road, proximity to the electricity network and optimal distance from airports. The results of the study show that the most favorable sites are mainly located in the northern part of the country, particularly in the Far North and North regions. There are also favorable sites in the North-West, South-West, West, Littoral and very little in the South while the central and eastern regions are not suitable. This is mainly due to the tropical forest that covers the entire region of East Cameroon and the low wind speed in these regions which is the determining factor for the installation of wind farms. The appropriate land for the installation of wind farms is approximately $2.56 \%$ corresponding to an area of $11,602.494414 \mathrm{~km}^{2}$. However, when we include the condition that a wind farm must have at least 4 $\mathrm{km}^{2}$ of surface area, is goes from $2.56 \%$ to $2.22 \%\left(11,602.494414 \mathrm{~km}^{2}\right.$ to $10,344.424539 \mathrm{~km}^{2}$ ); thus a surface reduction of approximately 1258.069875 $\mathrm{km}^{2}$. We can conclude that despite the fact that Cameroon does not have a huge potential for wind energy because of the low wind speed observed in the country, it is still possible to have some favorable sites for the installation of the parks wind. In addition, a study of hybrid solar-wind systems could improve the efficiency of the power plants in Cameroon.
\end{abstract}




\section{Keywords}

Wind Energy, Boolean Method, Geographic Information System (GIS), Cameroon, Wind Farm

\section{Introduction}

Today, Africa faces the challenge of producing more electricity to sustainably meet existing and future demand. Africa is a privileged continent in terms of wind resource regime. However, very little of this has been used. It is therefore essential to identify and define the amount of wind energy that could be exploited technically on the continent. Since wind energy use is associated with a multitude of location criteria, it should be systematically taken into account by spatial assessments to ensure its harmonization with socio-economic systems, infrastructure and ecosystems [1]. The negative effects of traditional methods of electricity generation on the environment have created the need for strategic planning and development of renewable and sustainable energy systems [2]. The development of wind farm projects that requires adequate planning and evaluation. In most cases, the location of wind farms depends on the wind resource (i.e. wind speed) of a site. However, in other criteria such as ecological, economic and social factors are also important during the planning phase to reach a decision to set up a robust wind farm [3]. One of the major challenges in developing wind energy in Africa is the lack of scientific data for policy formulation and decision-making that will contribute to the development of wind energy use. The information contained in the data could be useful for decision makers, public authorities, engineers, etc. to choose an optimal site [4]. This will ensure optimal investment and return on investment for wind farm developers. Clean domestic renewable energy may be the best option given the intense economic development and the resulting increase in energy consumption. The main obstacle to the wider deployment of renewable resources in Africa is the world's lowest fossil fuel price. As global growth in renewable energy projects accelerates site identification will become a priority, where a key element is minimizing the impact of development on the environment. As wind energy is a freely available low-carbon source of energy, decision-makers around the world have focused on it, as wind energy systems can reduce a country's dependence on energy. Fossil fuels and contribute to sustainable climate and energy development. However, wind energy does have some environmental impacts and land use constraints that need to be taken into account in order to achieve the main sustainability goals for biodiversity and ecosystem services [5]. Renewable energy is considered as one of the viable options given the intense economic development and the increase in energy consumption. With the maturity of advanced, economically viable and environmentally friendly technologies, wind energy has become one of the fastest growing renewable energy sources in the world [5]. 
Nowadays, renewable energies are preferable to fossil fuels because they are free of a charge, widely available and produce minimal pollution. The maturity of wind energy technologies allows us to use it as a source of electricity generation. In addition, the Enrs are not accessible in all geographical positions. It is clear that renewable energy systems can be exploited to their full potential if they are used in the right place. Therefore, given the importance of finding suitable locations for the use of wind energy, it is necessary to find the ideal locations for the construction of wind farms in Cameroon using the Boolean model of GIS software.

\section{Empirical Studies}

[6] uses the Boolean GIS software method to identify ideal locations for wind farm construction in the Middle East. The Boolean method is somehow of a stricter method than other positioning methods. Therefore, the selected sites will certainly have a higher energy potential using the Boolean method. They conclude that the results of their study could be useful for creating sustainable energy development prospects for natural resource-based systems and for facilitating national policies for energy transport and sustainable environment. [2] presents the analysis of the suitability of wind farm sites using a multicriterion decision-making (MCDM) approach based on geographic information system (GIS) modeling in the Kingdom of Saudi Arabia. The most suitable sites are 1) near Ras Tanura on the coast in the eastern province; 2) Turaif in the Al-Jawf region at the northern borders and 3) Al-Wajh on the coast in the western region. The central and southeastern regions are proving to be unsuitable mainly because of the scarcity of wind resources, the scarcity of people, and the lack of connectivity by road and electricity power network. [3] uses a fuzzy type 2 analytic hierarchy process is to determine the appropriate wind farm sites in Nigeria. The results of the study reveal that the best wind farm development sites are mainly located in the northern part of Nigeria, with Bauchi, Jigawa, Kaduna, Kano, Katsina, Plateau and Sokoto states being the most suitable for park projects wind. The area suitable for the installation of a wind farm in the country is estimated at about $125,728.6 \mathrm{~km}^{2}$, of which about $2650.1 \mathrm{~km}^{2}$ are considered perfectly suitable for the installation of a wind farm. [7] applies a geographic information system to determine the potential of wind power in Markazi province, western Iran. For this, they use a multi-criteria decision-making method and the site selection criterion (technical, environmental, economic and geographic standards) for the assessment of wind resources in the study area. The results were favorable for electricity production in line with international wind standards in western Iran. The results show that $28 \%$ of the study area has the capacity to install large wind farms. [8] makes an assessment of the suitability of wind and solar farms over a large area of Southern England $\left(17,094 \mathrm{~km}^{2}\right)$ using a multi-criteria GIS-assisted assessment. They find that wind energy adequacy is generally low, with only $0.5 \mathrm{~km}^{2}$ representing the "most appropriate" category. Solar fitness is 
higher overall; and a larger area $\left(294 \mathrm{~km}^{2}\right)$ in the "most appropriate" category, suggesting that the region is better suited to developing solar farms. [9] evaluates the usable potential of wind and solar power for Afghanistan using multi-criteria GIS decision analysis. Based on the zones, they estimated the wind and solar potential taking into account the technologies and conditions of the site. As a result, the calculated total annual production potential would be: $342,521 \mathrm{GWh}$ of wind energy, 140,982 GWh of solar photovoltaic energy and approximately $6000 \mathrm{GWh}$ of CSP energy (concentrated solar energy) representing 160 times the power supply existing in Afghanistan. [5] evaluates the potential wind energy available in Sweden using a GIS-based approach. They sought to estimate the terrestrial wind energy potential available in Sweden taking into account system performance, topographical limits, environmental and land-use constraints in the form of two restriction scenarios. The results obtained in this study suggest that Sweden has sufficient wind potential and land surface for wind farms, which can be used to meet future renewable energy targets in Sweden. The results of the study can draw the attention of policy makers to the sustainable development of wind energy in Sweden. [10] sets up a geographical information system with multi-criteria decision-making methods, in order to select the most feasible location for the installation of wind turbines in continental Ecuador. The results reveal that the site with the highest overall performance index is the Andean region of Ecuador, with an area of more than $617.5 \mathrm{~km}^{2}$. The overall performance index result indicates that the four selected multicriteria decision-making methods yielded similar results, where the value was equal to or greater than $75 \%$ of the maximum punctuation of an ideal location. In this context, the methods analyzed converge towards similar solutions and indicate that the multicriteria decision-making method is a powerful tool for selecting the ideal locations for wind farms. [8] Are doing a study on the combined use of geographic information systems (GIS) and spatial multi-criteria decision analysis to select the most appropriate sites for wind farm development projects. The results show that $12.20 \%\left(2787.78 \mathrm{~km}^{2}\right)$ of the suitable area is high in the study area, $17.06 \%\left(3899.78 \mathrm{~km}^{2}\right)$ of the average suitable area and $11.06 \%\left(2527.28 \mathrm{~km}^{2}\right)$ of the appropriate low area. They conclude that this scientific approach will enable resource managers in the planning process to make informed decisions. [11] uses Geographical Information Systems (GIS) associated with Multicriteria Analysis (MCDA) to select suitable sites for the establishment of wind power plants in Western Turkey. Evaluations are performed both at the (micro) grid and in the field (macro) and the two levels of deterministic and random data are used. The results reveal a high level of consensus on the most feasible sites between the different MCDA methods applied. The proposed methodology provides structured decision support, which can be applied to other energy site selection issues. [12] proposes a model based on the combined application of geographical information systems (GIS) and multi-criteria decision analysis (AMCD) for the identification of locations for the installation of wind farms in Serbia. The model takes into account 11 constraints and 
11 evaluation criteria grouped into economic, social and environmental groups. The results show that an area of $321 \mathrm{~km}^{2}$ in Vojvodina is perfectly suited to the installation of wind farms. The classification of viable sites using the MABAC method shows that a site near the village of Laudonovac (L8) is more suitable for the installation of wind farms in the province of Vojvodina. A sensitivity analysis, performed by modifying the input weights of the clusters, indicates that the model is useful for identifying suitable locations for the development of wind farm projects, as well as for assessing the suitability of projects already authorized for the construction of wind farms. They conclude that the designed model could also help to successfully identify the appropriate locations for the installation of wind farms in other areas with similar geographical conditions. [13] Propose and implement an integrated evaluation framework for the selection of the most suitable sites for wind farm development projects in Greece using the combined use of geographic information systems (GIS) and spatial multi-criteria decision analysis. The proposed decision tool is thus able to obtain the optimal locations for the projects, as well as the adequacy score of the projects already under license. The results of their study confirm the potential role of planners in the designation of wind farm development areas. [14] applies a multi-criteria decision-making approach using an analytical hierarchy process with an AHPOWA ordered weighting function to derive a wind farm land suitability index and a classification in a GIS environment for Oman. Different selection criteria were considered, including economic (distance to the road, slope of the land), social (urban area), environmental (historical sites, wildlife and nature reserves) and technical (wind energy density, adaptation demand for energy, percentage of sustainable wind, intensity of turbulence). [15] uses fuzzy approaches of different multi-criteria decision making (MCDM) methods combined to address a trend decision problem such as the selection of terrestrial wind farm sites in the Murcia region, located southeast of Spain. They apply the fuzzy analytic hierarchy process (FAHP) to obtain the criteria weights, while the fuzzy technique for the order of similarity preference with the ideal solution (FTOPSIS) is used to evaluate the alternatives. A geographic information system (GIS) is applied to obtain the database of alternatives and criteria transformed into a decision matrix.

However, no study has been done to locate suitable sites for the establishment of wind farms in Cameroon. This study therefore fills this gap.

\section{Description of Study Area, Data and Methodology}

\subsection{Study Area}

\subsubsection{Presentation of Cameroon}

Located between the equator and the tropics, Cameroon, located at $6^{\circ} \mathrm{N}$ latitude and a longitude of $12^{\circ} \mathrm{E}$, is in the form of a triangle of Area $475,650 \mathrm{~km}^{2}$ (Land: 98.8\%; Water: 1.2\%) Surrounded by Lake Chad, the Atlantic Ocean, and the Congo Basin, it is bordered by Chad (North), Central African Republic (East), 
Congo, Gabon, Equatorial Guinea (South) and Nigeria (West). The relief of Cameroon is very diversified: We have in the western part of the country, wooded hills as well as a long chain of mountains dominated on all the Atlantic coast by Mount Cameroon (4095 m). In the center, pastures of altitude in the Adamawa mountains at $2500 \mathrm{~m}$ height. In the north, the savanna is dominant as well as some mountain ranges (the Mandaras mountains) on the border with Nigeria. In the South, tropical forests and swamps. The country is subdivided into 10 administrative regions: Far North (Maroua); North (Garoua); Adamawa (N'gaoundere); East (Bertoua); Center (Yaoundé); North West (Bamenda); Southwest (Buea);West (Bafoussam); Littoral (Douala); and South (Ebolowa). Linguistically speaking, the population is bilingual (English and French are the official languages), with the majority been French (80\%) and an English minority (20\%). The population is estimated at just over 15 million souls. it is unevenly distributed with a density estimated at about 10 inhabitants per $\mathrm{km}^{2}$ in the SouthEast and above 100, with peaks at 200 in the Western Region. 56\% of the population is under 20 years old and about $50 \%$ of the total population live in urban areas, with about $50 \%$ in the cities of Douala (economic headquater) and Yaounde (administrative and political headquater).

\subsubsection{Context of Electric Power in Cameroon}

The electricity generation fleet managed by ENEO includes three hydroelectric plants, two of which supply the RIS, and nine thermal power plants connected to the grid, of which eight (8) are on the RIS. At the end of 2011, there are also 27 isolated generating stations, of which 12 exist in RIS-assisted areas, 8 in the North regions served by the INR, and 6 more are located in the Eastern network area. The latter will be designated by RIE, by analogy with RIS and RIN. Thus, more than $56 \%$ of the workforce of the electric park is concentrated in the large zone of the South with $83 \%$ of the main plants connected to the network and $44 \%$ of the isolated plants. This should reflect the relative importance of the demand for the Great South network. Hydroelectric generation accounted for the bulk of national production, with over $92 \%$ of the national production of power plants managed by ENEO over the period 2005-2011. Isolated thermal power plants represent $1.6 \%$ of the national production of ENEO on average, with a maximum of $1.8 \%$ recorded in 2011.

\subsection{Data Description of Wind farm}

In this study, Worldclim 2.0 provides monthly wind speed data at $10 \mathrm{~m}$ above the ground at a $1 \mathrm{~km} \times 1 \mathrm{~km}$ grid size resolution, which was used as a starting point for estimating wind potential. For each cell in the grid, a wind speed distribution curve was calculated using Worldclim data, extrapolated to the proposed wind turbine hub $(100 \mathrm{~m})$. The grouping of months with an above-average value forms the peak season. These are the months of January to May for the mean wind speed Figure 1 . The average of these different months gives us a raster that characterizes the high season Figure 1. The grouping of months with a 

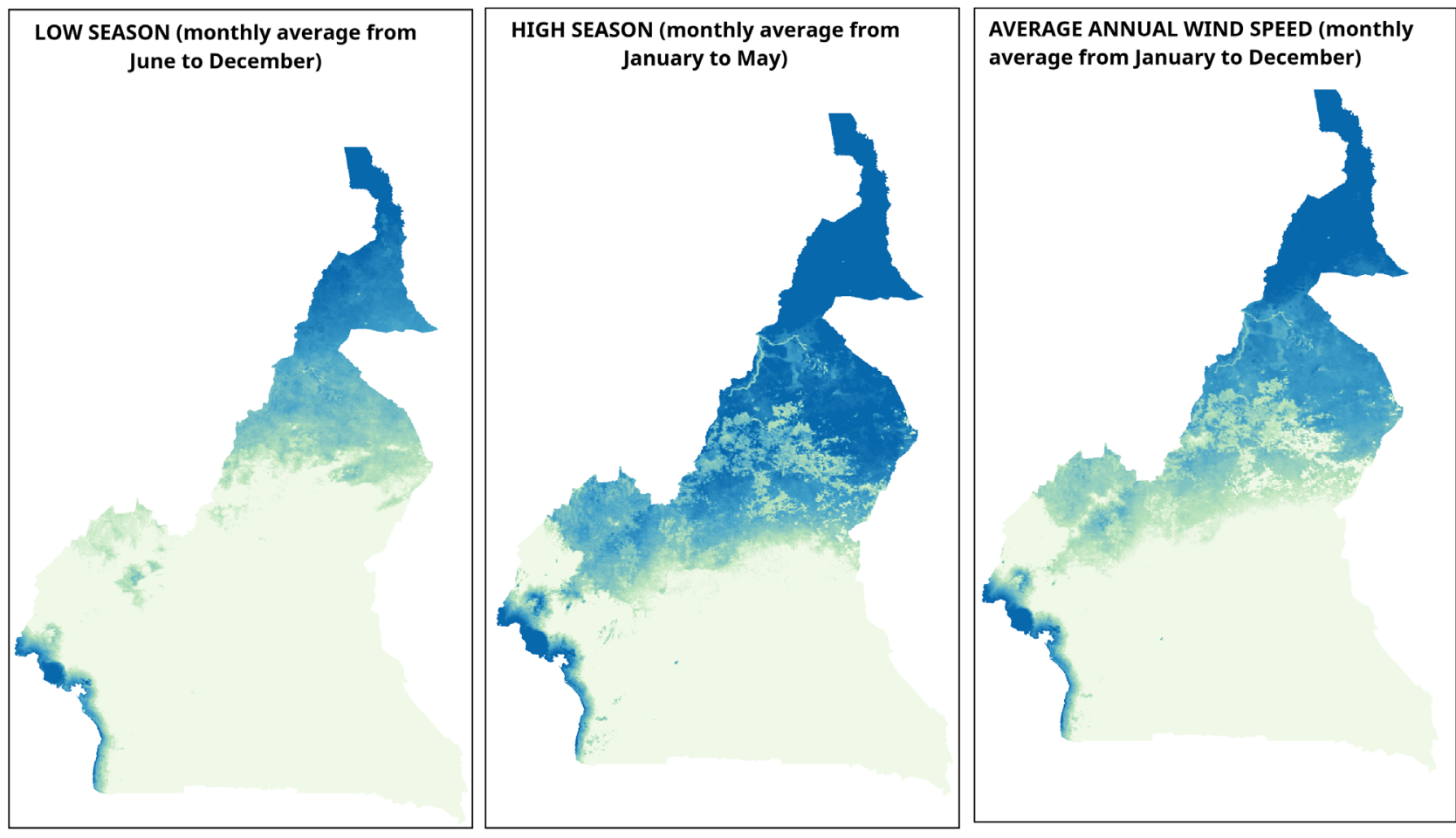

\section{Average wind speed variation}

$<1.6 \mathrm{~m} / \mathrm{s}-$ Not suitable

$1.6-1.9 \mathrm{~m} / \mathrm{s}$ - Low suitable

$1.9-2.2 \mathrm{~m} / \mathrm{s}$ - Moderate suitable

$2.2-3 \mathrm{~m} / \mathrm{s}$ - High suitable

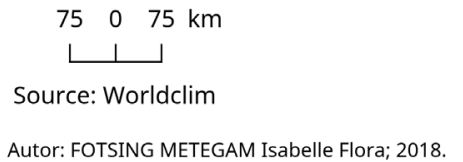

Figure 1. Wind potential (wind speed at $10 \mathrm{~m}$ ).

value below average forms the low season. These are the months of June to December for the average wind speed Figure 1. The average of these different months gives us a raster that characterizes this low season Figure 1. Spatially, we can also notice that areas with high wind potential are in the north of the country consisting of three regions. This part of the country is also the one with the lowest electrification rate. This would already guide us to future sites if we want to combine electricity demand with the electric potential.

Figure 2 shows the energy map of Cameroon. Figure 2 shows the spatial distribution of hydroelectric and thermal power plants in Cameroon as well as the Cameroonian electricity network. There is also the road network and the various rivers of Cameroon.

Table 1 describes the type of data used in this study. Table 1 shows the format of the data used as well as the geometry and the source of these data.

\subsubsection{Wind Speed}

The calculation of the wind speed at different heights was made from Hellman's relation, which is the most common and easiest relation to associate the wind speed with two heights:

$$
\mathrm{V} / \mathrm{Vr}=(\mathrm{H} / \mathrm{Hr})^{\alpha}
$$




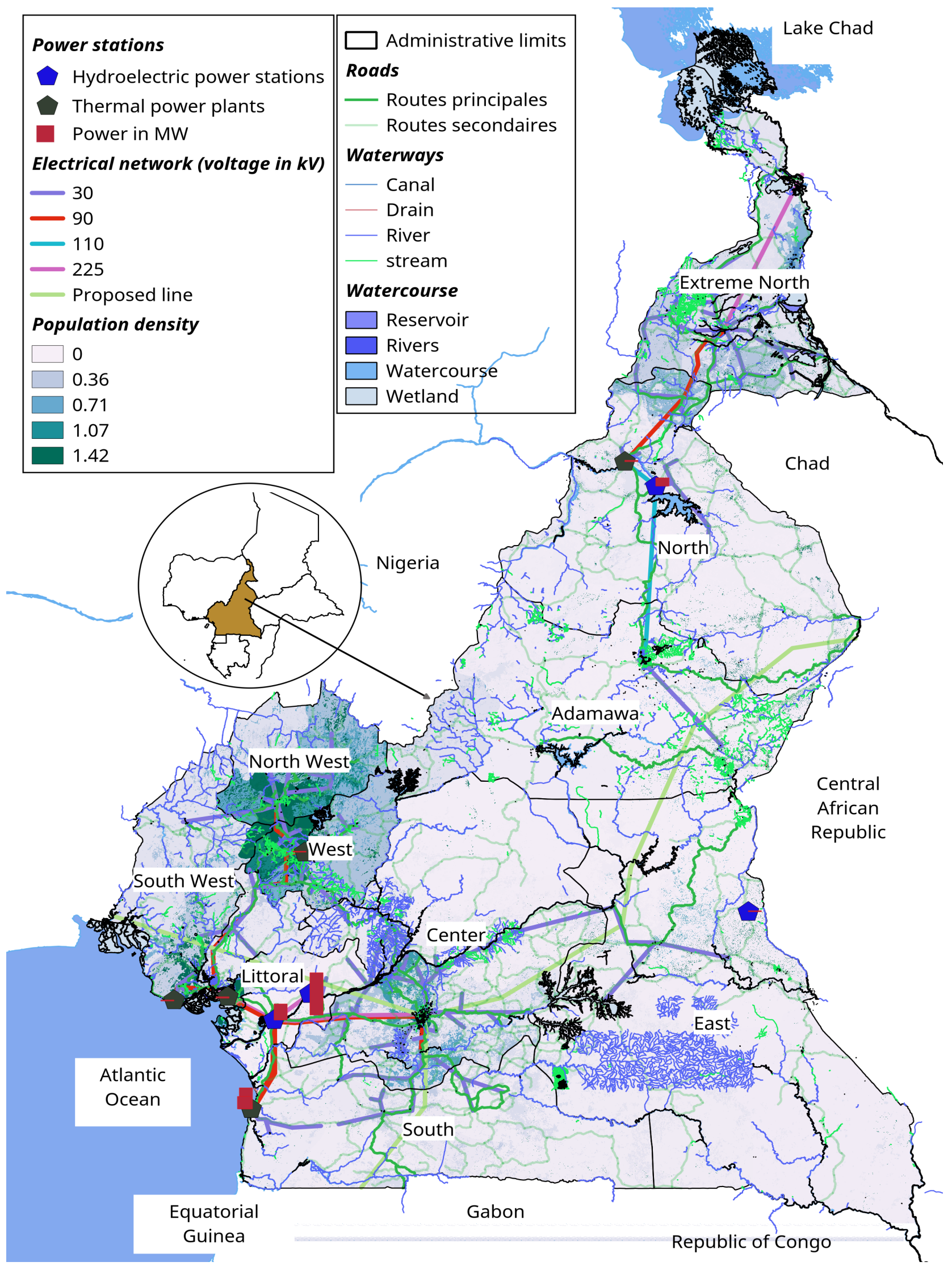

Figure 2. Energy map of Cameroon (Source: Worldpop 2010, OSM 2018, World Bank 2018, GADM 2018). 
Table 1. Description of the study data.

\begin{tabular}{|c|c|c|c|}
\hline Data & Types (format) & Geometry & Sources \\
\hline $\begin{array}{l}\text { Administrative limits of Cameroon } \\
\text { (regions, departments, districts) }\end{array}$ & Vector (shapefile) & polygon & GADM, 2018 [16] \\
\hline $\begin{array}{l}\text { Map of average monthly wind speed over } 12 \text { months } \\
\text { from } 1970 \text { to } 2000 \text { in Cameroon }\end{array}$ & Raster $\left(1 \times 1 \mathrm{~km}^{2}\right)$ & & Worldclim version 2.0, 2018 [17] \\
\hline Map of population density in Cameroon & Raster $(1 \times 1$ ha $)$ & & Wordpop, $2010[18]$ \\
\hline Map of Cameroon Power Plants & Vector (shapefile) & Point & World Bank, 2018 [19] \\
\hline $\begin{array}{l}\text { Hydrological map of Cameroon (streams, navigable } \\
\text { waters, rivers, rivers, wetlands, reservoirs...). }\end{array}$ & Vector (shapefile) & Line polygon & $O S M, 2018[20]$ \\
\hline Map of land use in Cameroon & Vector (shapefile) & Polygon & OSM, $2018[20]$ \\
\hline $\begin{array}{l}\text { Map of the road network (inter_state, primary, } \\
\text { secondary roads....) in Cameroon. }\end{array}$ & Vector (shapefile) & Line & OSM, $2018[20]$ \\
\hline Map of Cameroon power grid & Vector (shapefile) & Point & World Bank, 2018 [19] \\
\hline Map of elevation in Cameroon & Raster $\left(1 \times 1 \mathrm{~km}^{2}\right)$ & & USGS/NASA SRTM data, 2018 [21] \\
\hline Map of Cameroon airports & Vector (text format csv) & Point & ADC (Cameroon Airport $), 2018$ [22] \\
\hline
\end{tabular}

where $\alpha=0.4$ for small towns, villages, forests, agricultural land characteristic of Cameroon.

Where $\mathrm{V}$ is the wind speed at the desired height $\mathrm{H}, \mathrm{Vr}$ is the wind speed at the reference height $\mathrm{Hr}$, and $\alpha$ is the coefficient of friction (roughness depending on the terrain), also called Hellman exponent. The Hellman exponent is a complex function of local climate, topography, surface roughness, environmental conditions and atmospheric stability that all depend on the date the wind speed was recorded (day or night).). The best way to evaluate available wind sources on a site is to use the wind energy density parameter. The density of wind energy is measured in $\mathrm{W} / \mathrm{m}^{2}$ and indicates the amount of wind energy available at a given location for the production of electricity by a wind turbine. The average wind density is obtained by the formula:

$$
\mathrm{P} / \mathrm{S}=1 / 2 \rho \mathrm{V}^{3}
$$

where $\mathrm{P}$ is the average wind power in watts, $\rho$ is the density of the air at the studied location $\left(1225 \mathrm{~kg} / \mathrm{m}^{3}\right.$ for the present case), $S$ is the swept area in blades of the wind turbine in $\mathrm{m}^{2}$ and $\mathrm{V}^{3}$ is the average of the wind speed to the cube.

NB: These different calculations will take into account the resolution of the different layers.

In addition, the average wind speed is a decisive economic factor for the economic viability of the wind farm project on a given site. For a site to be considered, the lowest average wind speed must match the technical and economic feasibility of the project. The most important economic factor to consider when building a wind farm is the wind speed at the given location. Areas where the average wind speed is greater than $4 \mathrm{~m} / \mathrm{s}$ are considered to have continuity, with 
the recommendation being to select the areas with the highest wind speed values Wind speed data are from Worldclim 2.0.

\subsubsection{Distance from the Electrical Network}

Long transmission lines between wind farms and the grid are associated with wiring and power loss costs. Wind farms must be located near the electricity grid. One of the biggest problems in reducing wind farm construction costs is reducing the cost of building energy transmission infrastructure. When choosing the location, it is necessary to take into account the availability and access to the existing electricity network. For the current analysis, the national grid and power plant maps are extracted from Eneo's electrical data register. ENEO is the national electricity company responsible for the management of electrical energy in Cameroon. In this study, a distance of $10,000 \mathrm{~m}$ around the electricity grid was taken as a suitable area for the installation of wind farms. A safety distance of $250 \mathrm{~m}$ is however observed between the wind park and the power lines. Power grid data is from the World Bank 2018.

\subsubsection{Distance from Residences}

The social implications of wind farms, including the impact of noise, shadows and safety, and the impact on people in terms of potential injury from a damaged propeller, are considered to be very important constraints. Buffer (preventive) distances in residential areas to avoid noise, nuisance and the natural environment must be defined. The impact of noise should be assessed in relation to the nature and character of noise-sensitive areas and the relevant legislation. This is a very important criterion for the establishment of wind farms. In all similar studies, these distances are well defined. However, these buffer distances are different in different studies and their selection needs to be justified on a caseby-case basis by the national planning authority. It is important that wind farm locations are within a reasonable distance of settlement areas to minimize transmission losses. Numerous studies present a range of distances compared to colonies where the analysis of the installation of a wind farm. The distances on either side of this beach are totally unfeasible. Data on residential areas are obtained from Open Street Map (OSM, 2018). The safety distance is $2000 \mathrm{~m}$ around residential areas.

\subsubsection{Road Distance}

To minimize wind farm construction and maintenance costs, it is necessary that the distance between the proposed wind farm location and the road network be as short as possible. In most wind farm site assessments, areas furthest from roads are considered less suitable than those closer to roads. However, there is no generally valid definition of a maximum distance between wind turbines and the road network. The specificity of equipment transport for the installation and subsequent maintenance of wind turbines is reflected in the need to secure the road network at the wind farm site, making maximum use of the existing road network. In order to reduce transport costs, it is preferable that the distance 
from the road be as small as possible. We took a distance of $10.000 \mathrm{~m}$ from a roads as a favorable area for the establishment of wind farms. A safety distance of $500 \mathrm{~m}$ is however observed between the wind park and the power lines. The route data comes from Open Street Map 2018.

\subsubsection{Airport Security Distance}

Wind turbines can interfere with the radar signal from aviation and would require a large buffer zone around airports. Most similar studies have a buffer distance around airports. For our study, we will take a distance of 3,500 m around airports. The relative data on the position of airports in Cameroon come from Cameroon Airport (ADC, 2018).

\subsubsection{Slope}

Accessibility for the installation and maintenance of wind turbines is hampered by the steep slope of a terrain. In the literature, the maximum permitted slope threshold is $10 \%$ to $30 \%$. Due to the additional costs of construction and maintenance, topography with steep slopes is generally considered inappropriate for the development of wind farms. In the physical sense, wind farms must be located in appropriate locations. Areas with steep slopes are generally considered less appropriate due to additional construction and maintenance costs. In this study, a slope of $10 \%$ was taken as the maximum threshold. The elevation map from which the slope is drawn is from USGS/NASA SRTM data.

\subsubsection{Distance from Protected Areas}

In order to avoid or reduce the negative impact on the environment, it is desirable to place wind farms as far as possible from protected areas. Wind farms should be located in areas that would be least interfering with land use. In this study, a distance of $300 \mathrm{~m}$ was made for forests and parks. A distance of $400 \mathrm{~m}$ has also been taken as a safety zone around lakes and rivers and wetlands. The land cover data come from OSM 2018.

\subsubsection{Altitude}

In the physical sense, wind farms must be located in appropriate locations. Areas with high altitudes are generally considered less appropriate because of the additional costs of construction and maintenance. In this study, an altitude of up to $2000 \mathrm{~m}$ was taken as the threshold. The elevation map is from USGS/NASA SRTM data.

\subsubsection{Plant Required}

We recall here that we install wind power plants and not small wind turbines for the supply of a house or other. These wind farms will be connected to the national grid to increase its production. The required area for the installation of a wind farm is an area of at least $4 \mathrm{~km}^{2}$.

Figure 3 shows the distribution of the different input data of our study. This is the spatial distribution of the power grid, roads, waterways, elevation, slope, protected areas, residential areas and airports. 

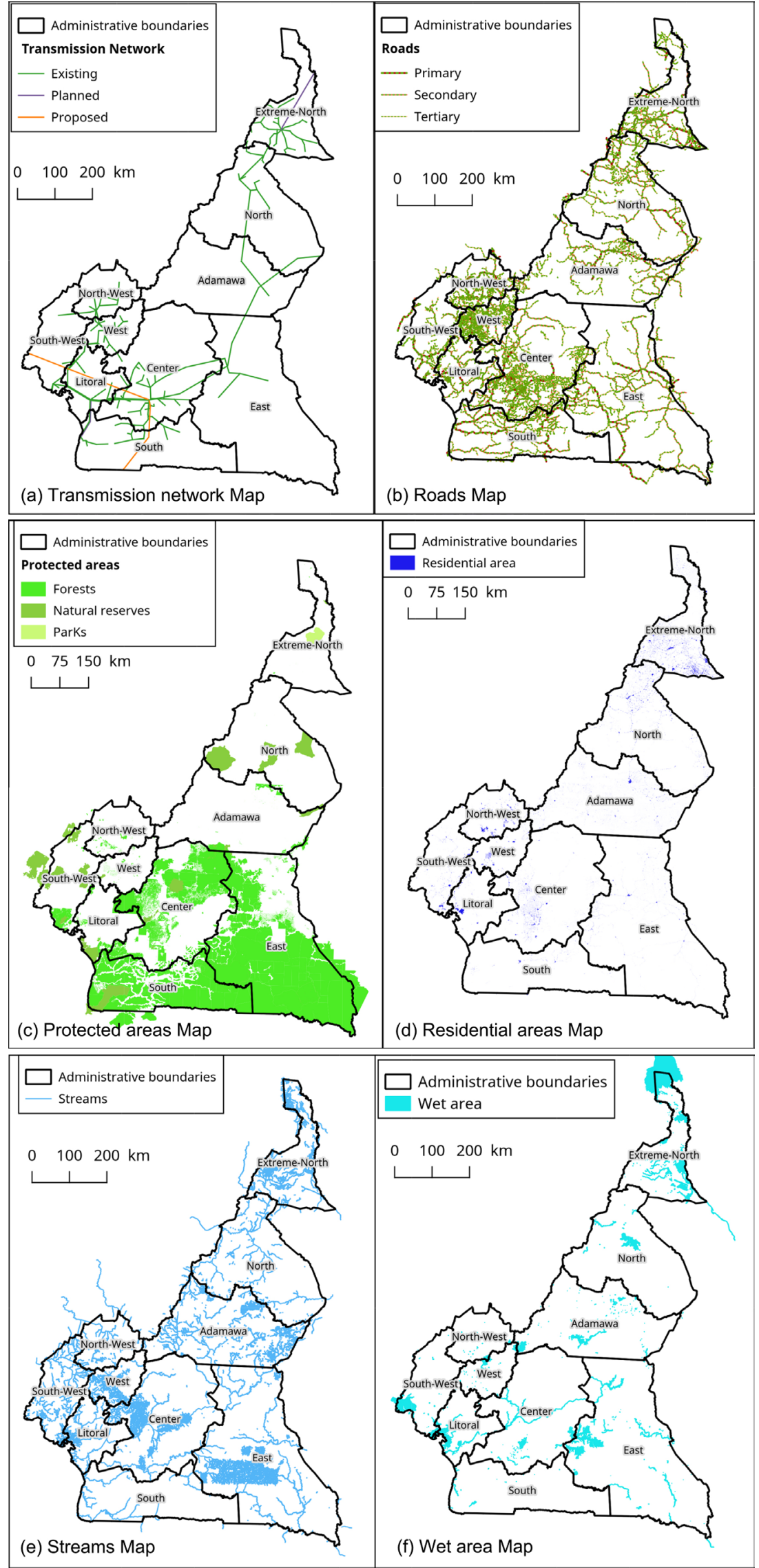


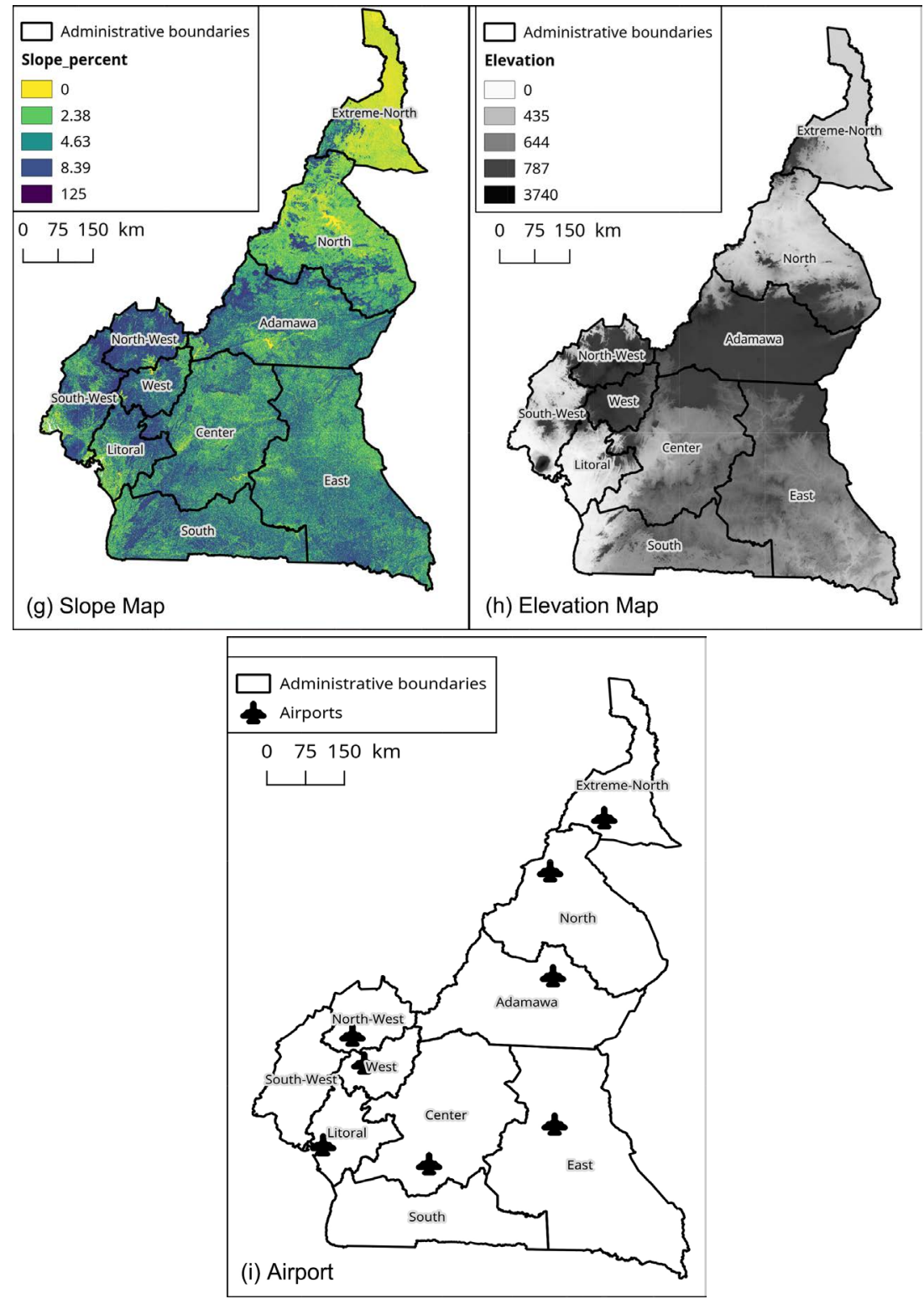

Figure 3. Evaluation data.

\subsection{Methodology}

\subsubsection{Geographic Information Systems}

Geographic Information System (GIS) has been used as a research and application tool since the 1970s. It covers a number of academic fields, including wind technology. GIS is designed to store, retrieve, manipulate, analyze and map geographic data [23]. Raster and vector are the two types of coverage representation that the GIS works with. The raster is represented by a rectangular grid called pixels that contains specific information based on a specific geographic location. The vectors manage a geometrical figure (points, lines and polygons) defining the limits associated with a reference system. The storage of this information is presented in a geodatabase that provides an order, structure and standardization of the data. All geographic information was processed as a raster in this search 
using continuous analysis of spatial variables such as: wind speed, terrain elevation, and vegetation cover, among others. GIS is a powerful tool for collecting and organizing spatial data, with many successful examples identifying potential sites for renewable energy production appearing [9] [23]. Frame processes are faster in evaluating problems, including mathematical combinations such as Boolean methods. The Boolean method in a GIS environment is based on criteria represented by a layer of geo-referenced map information; consequently, each point of the territory has received a value concerning the activity of the object of the decision which is 0 for not appropriating and 1 for appropriating. The free software GRASS GIS.7 and QGIS 2.18 were used to pixelate and standardize the data layers in this search. With this starting point and the generated inputs, statistical calculations were also made in GRASS and the layout of the figures in QGIS.

\subsubsection{Boolean Logic}

The Boolean logic model is the easiest way to combine layers in a GIS. The combination of layers in this method is based on the zero-one law, and the final result of the model is a map divided into two classes totally appropriate (class 1 ) and totally inappropriate (class 0 ). This model has low flexibility and rigor. Once the layers are formed on the basis of the Boolean model, the resulting layers are combined using the AND operator by the multiplication of layers in raster layers. The AND operator, based on an intersection logic operating in the raster layers, is as follows: if both input values are true, the output takes a value of 1 and if an input value is false and the other is true, the relevant cell has 0 in the output [24].

\section{Results and Discussions}

In this analysis, Worldclim provides daily wind speed data at $10 \mathrm{~m}$ above ground at a grid size resolution of $1 \mathrm{~km}{ }^{\star} 1 \mathrm{~km}$, which served as a starting point for estimating resource potential. For each cell in the grid, for each cell in the network, a wind speed distribution curve was calculated using Worldclim data, extrapolated to the hub height of the proposed wind turbine $(100 \mathrm{~m})$. The other important parameter that determines the performance of a wind farm is the distribution of wind speed. This characteristic can be very essential in wind resource assessments. The grouping of months with an above-average value forms the peak season. These are the months of January to May. The average of these different months gives us a raster that characterizes this high season. Grouping months with below average value forms the low season. These are the months of June to December. The average of these different months gives us a raster that characterizes this low season. The different seasons as well as the annual average of the wind speed distribution in Cameroon is illustrated in Figure 1.

We can also see in Figure 4 have the extrapolation of the wind speed to $100 \mathrm{~m}$ of height and the density of power corresponding to this height. Spatially, we can also notice that areas with high wind potential are grouped in the same group (Far North). This part of the country is also the one with the lowest electrifica- 
tion rate. This would already guide us to future sites if we want to combine need and potential.

Nine factors used in this study were combined with the Boolean method to find the most suitable location for the installation of wind farms in Cameroon. Figures 5-8 show the economic, planning, physical and ecological factors of the wind farm, respectively. The results were obtained on the basis of the Boolean logic that affected the value 1 at the appropriate site for a wind farm and the value 0 at the unsuitable site for a wind farm. Figure 9 shows the distribution of suitable lands and unsuitable areas. Figure 10 shows Design diagram in this studie and Figure 11 shows GIS-based Model for wind farm site selection.

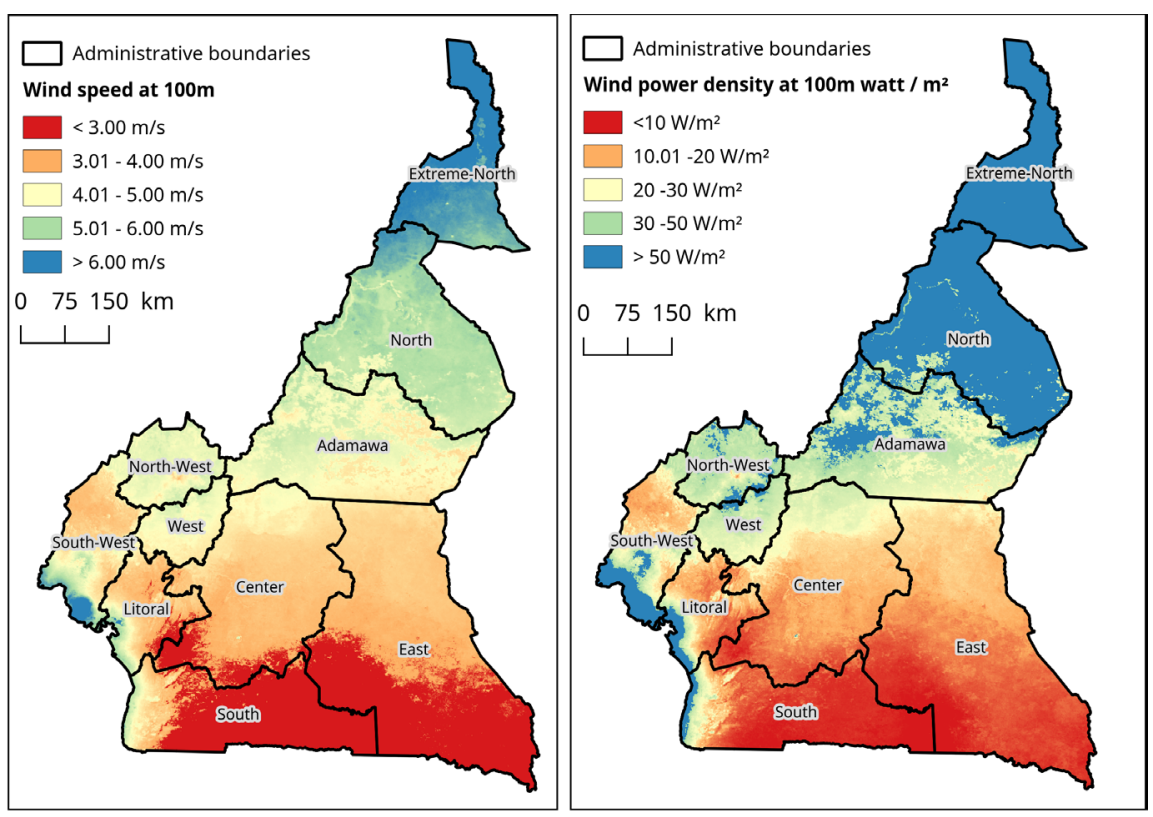

Figure 4. Wind speed at $100 \mathrm{~m}$ in $\mathrm{m} / \mathrm{s}$ and wind power density at $100 \mathrm{~m}$ in Watt $/ \mathrm{Km}^{2}$.

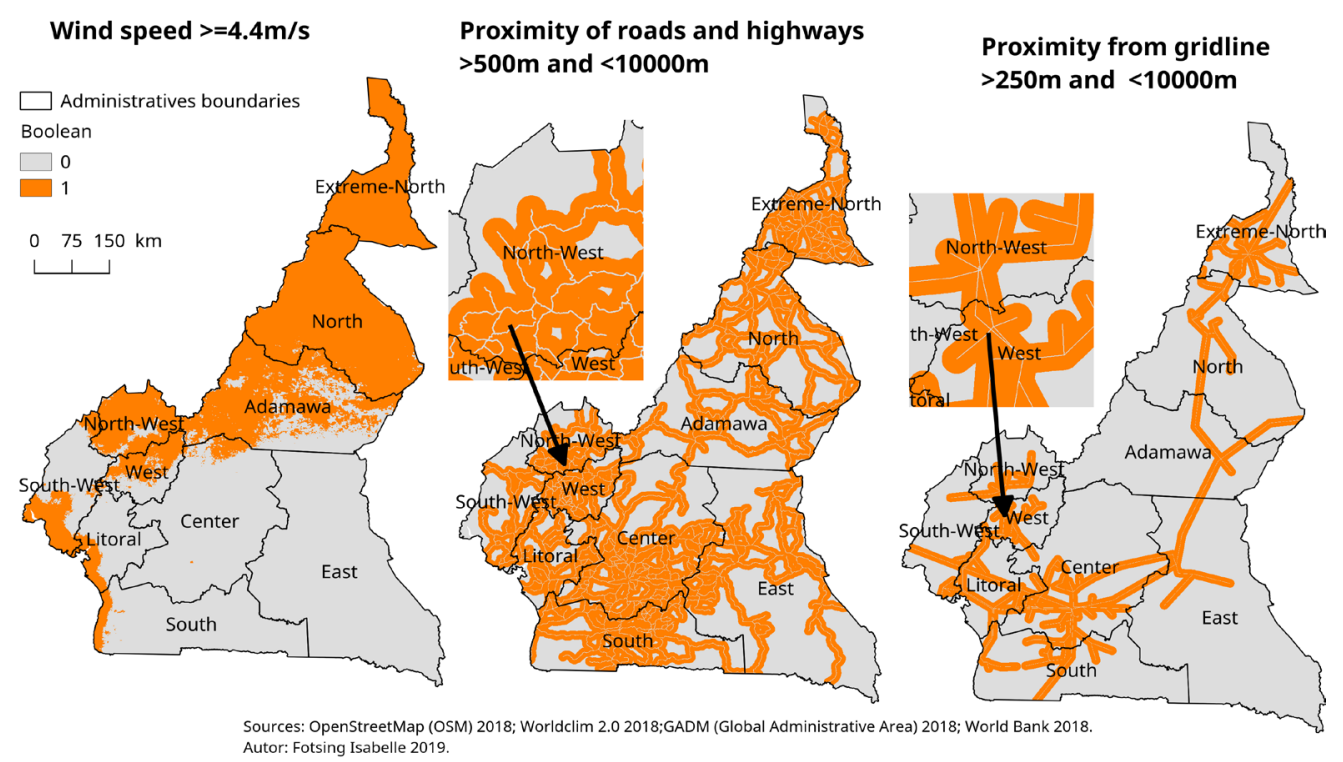

Figure 5. Economic criteria from chosen wind farm site selection. 


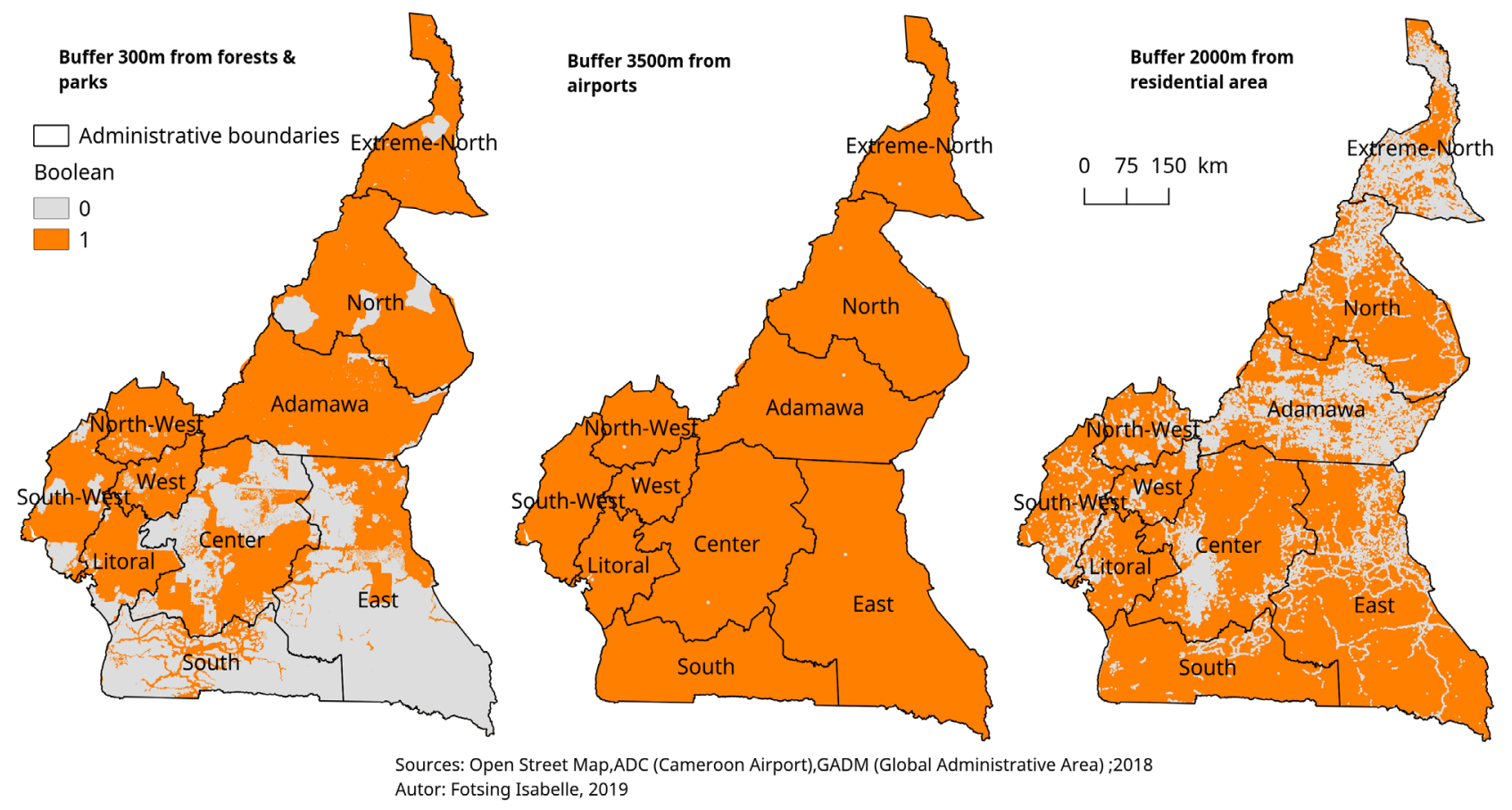

Figure 6. Planning criteria from chosen wind farm site selection.
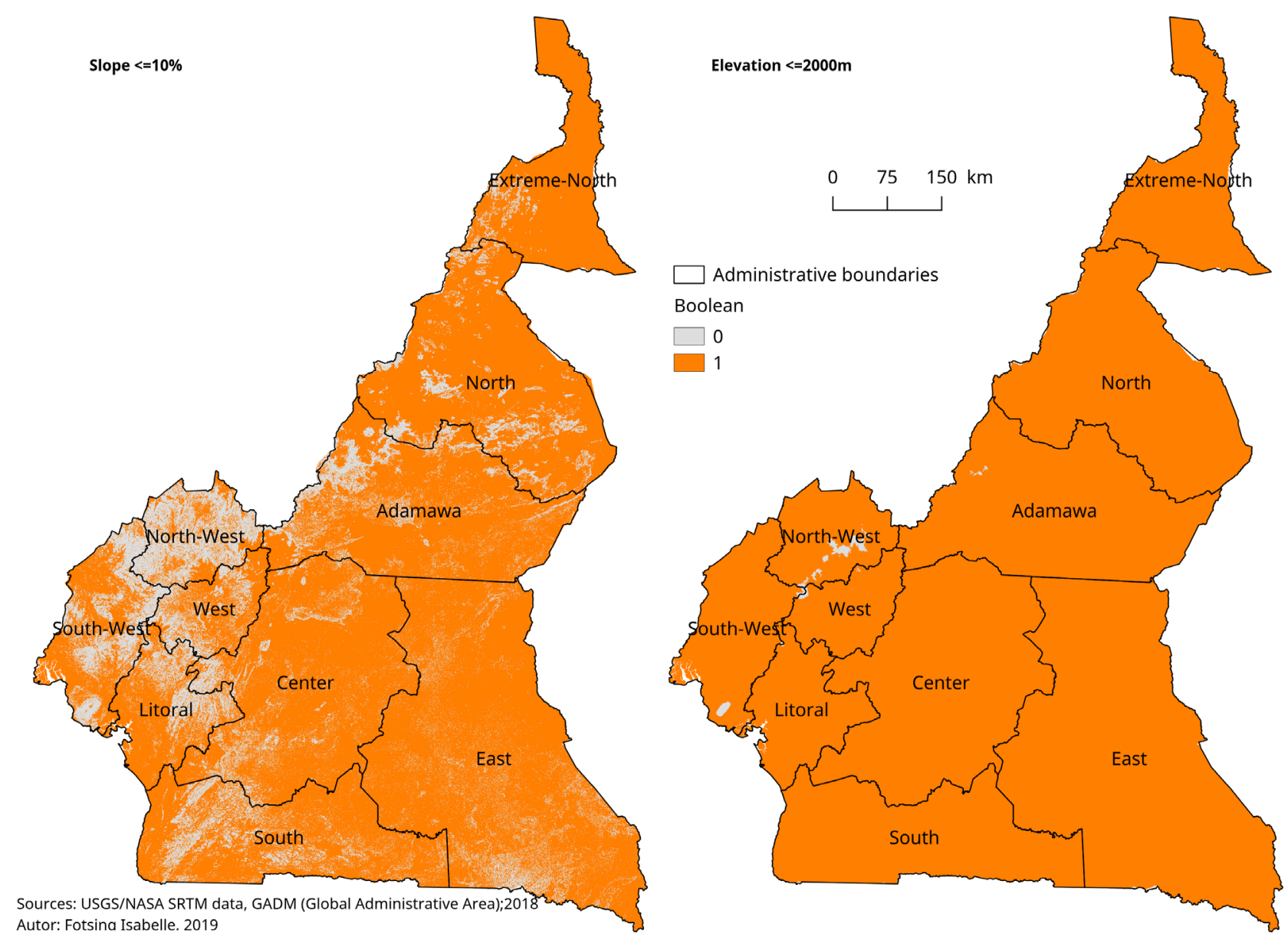

Figure 7. Physical criteria from chosen wind farm site selection. 


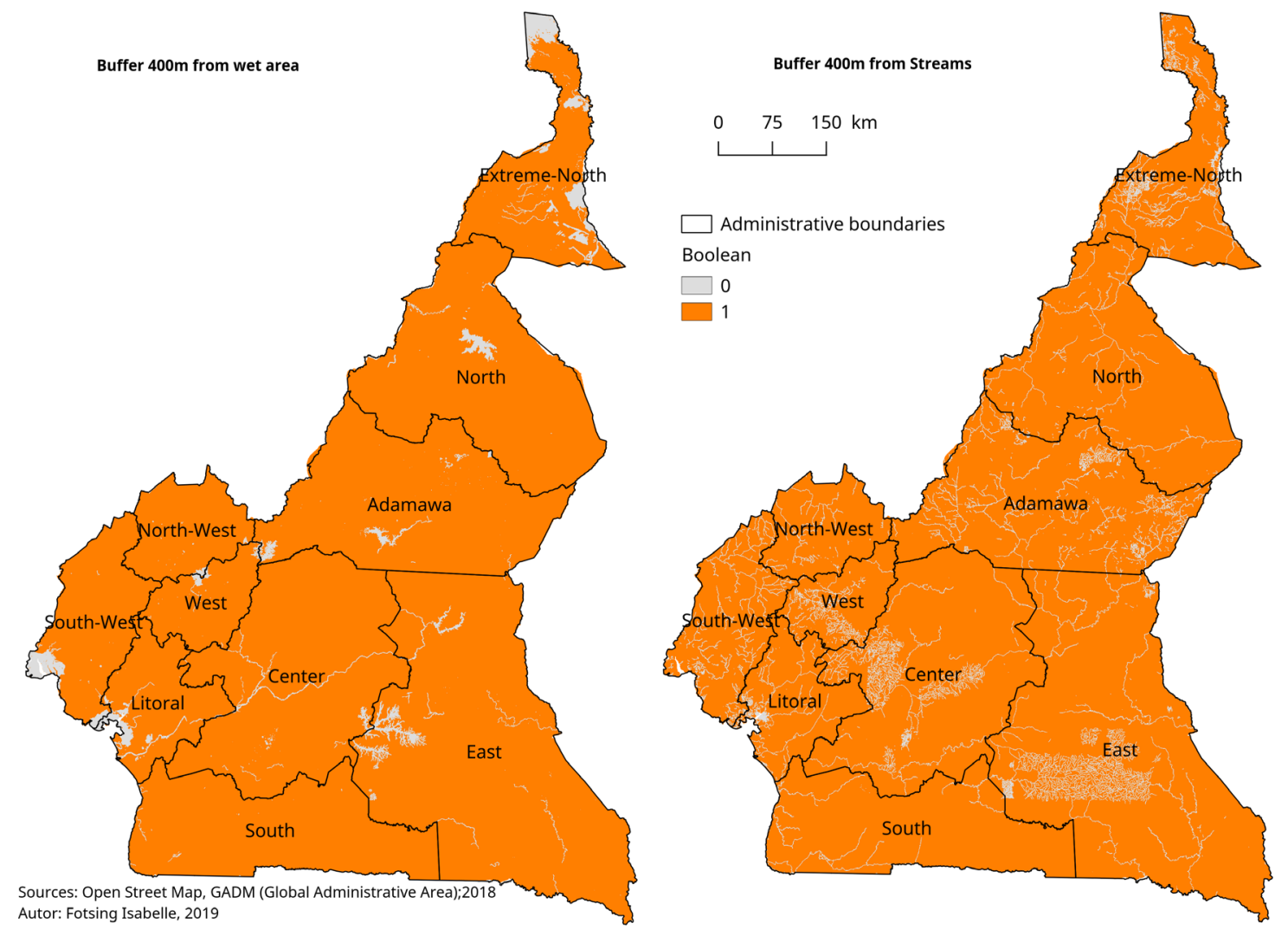

Figure 8. Ecological criteria from chosen wind farm site selection.
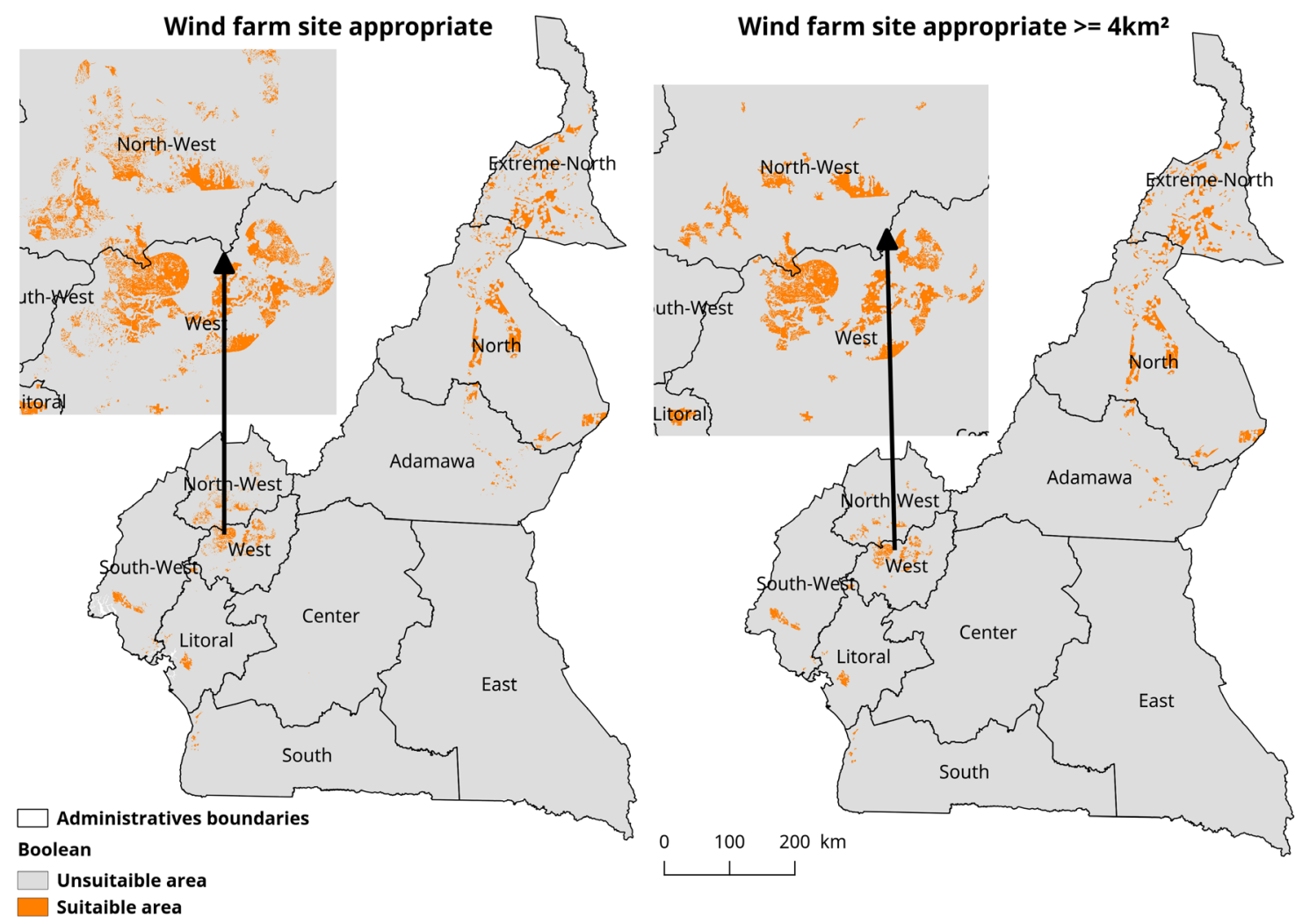

Unsuitaible are

Figure 9. Wind farm site suitable. 


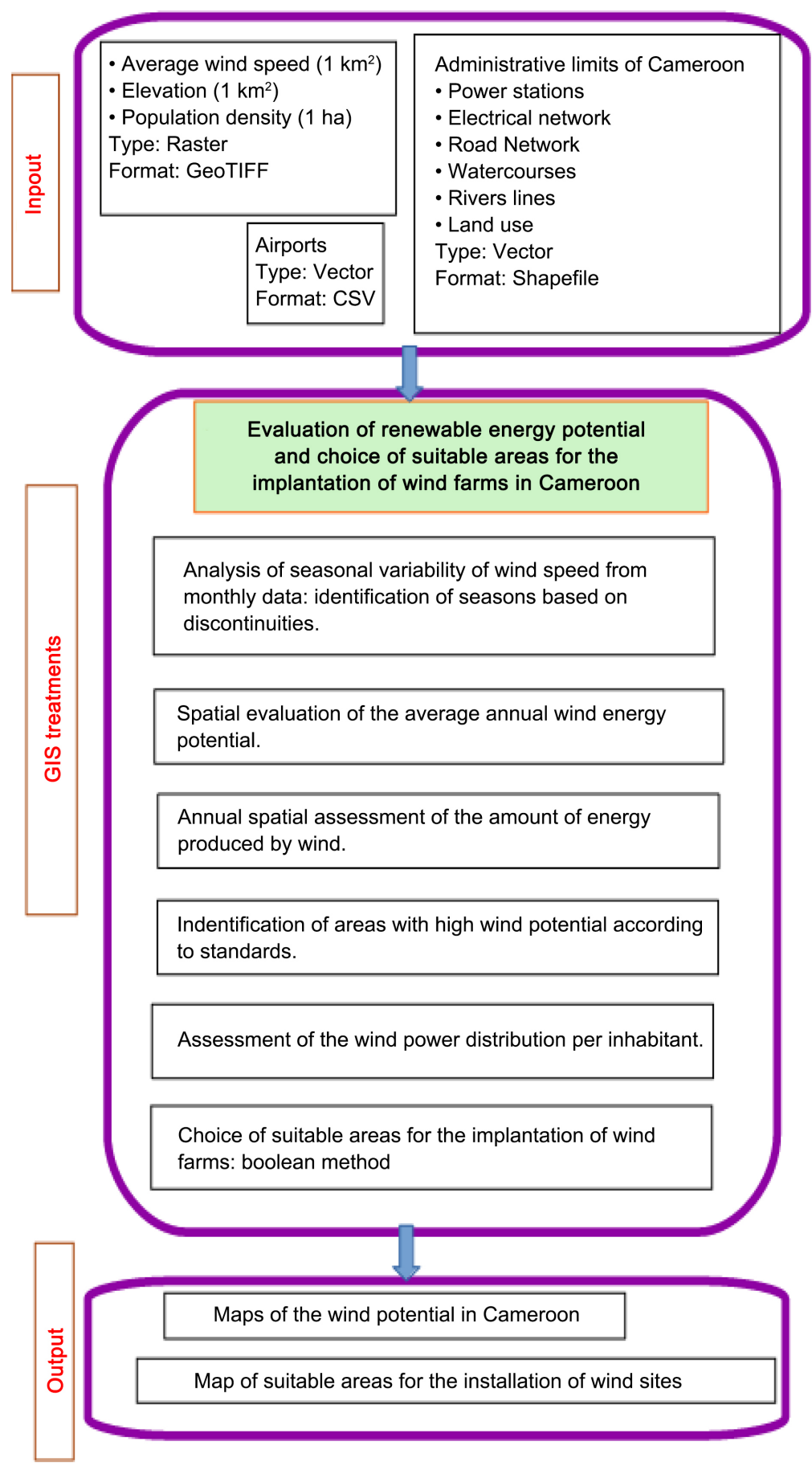

Figure 10. Design diagram.

The appropriate lands for the installation of wind farms are approximately $2.56 \%$ corresponding to an area of $11,602.494414 \mathrm{~km}^{2}$ Figure 12 . However, when the condition is included that a wind farm must have at least $4 \mathrm{~km}^{2}$ of surface [19], we go from $2.56 \%$ to $2.22 \%\left(11,602.494414 \mathrm{~km}^{2}\right.$ to $\left.10,344,424,539 \mathrm{~km}^{2}\right)$. That is to say a reduction in surface area of approximately $1258.069875 \mathrm{~km}^{2}$ Figure 13 and Figure 14. 


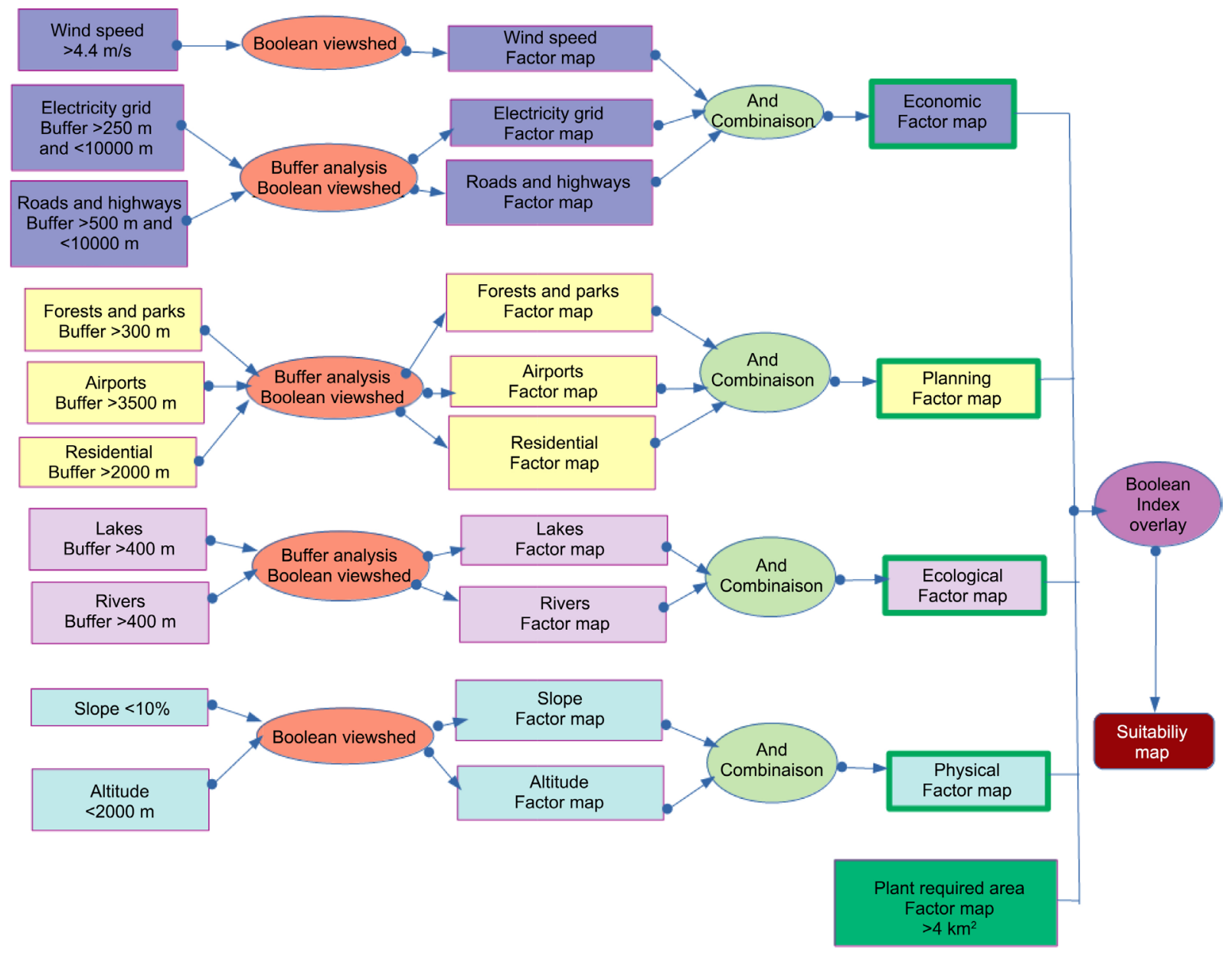

Figure 11. GIS-based Model for wind farm site selection.

The usable area for the wind farms is $10,344.424539 \mathrm{~km}^{2}$. The suitable locations are in orange in Figure 9. The unsuitable sites are in gray in Figure 9 and in white, we have the surfaces lower than $4 \mathrm{~km}^{2}$ which is the minimal surface that must have a wind farm connected to the electric network. The results of the study show that the favorable sites are mainly located in the northern part of the country, particularly in the Far North and North regions. There are also favorable sites in the North-West, South-West, West, Littoral and very little in the South. However, the Central and Eastern regions do not have appropriate sites. This is mainly due to the tropical forest that covers the entire region of East Cameroon and the low wind speed in these regions is the determining factor for the installation of wind farms.

It should be noted here that we did a study on Onshore sites. So we took as total area of Cameroon $465,400 \mathrm{Km}^{2}$ which is the land area. The stress map describes areas that are not conducive to the development of wind farms and should not be considered due to social and environmental factors. These areas are excluded from the assessment process as their use is prohibited in wind farms. This map was generated using the social/environmental criteria provided in Table 2. 


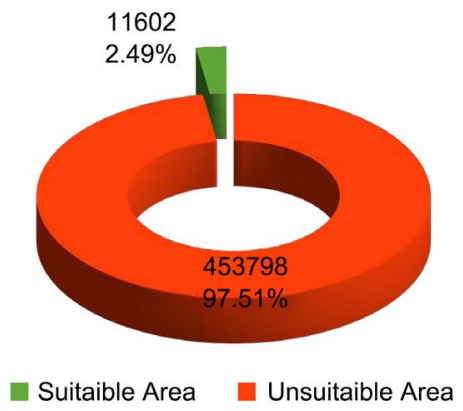

Figure 12. Suitable and unsuitable areas in $\mathrm{km}^{2}$ for wind farm development in Cameroon.

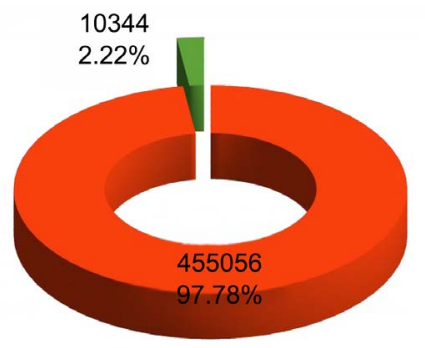

- Suitaible Area (4sp·km) — Unsuitaible Area

Figure 13. Suitable $\left(4 \mathrm{~km}^{2}\right)$ and unsuitable areas in $\mathrm{km}^{2}$ for wind farm development in Cameroon.

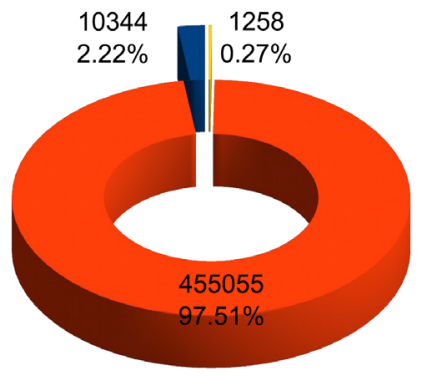

\section{Suitaible Area (4sp $\mathrm{km})$ - Unsuitaible Area Lost Area}

Figure 14. Suitable $\left(4 \mathrm{~km}^{2}\right)$, unsuitable and lost areas in $\mathrm{km}^{2}$ for wind farm development in Cameroon.

Table 2. Restriction criteria from chosen wind farm site selection studies.

\begin{tabular}{|c|c|c|c|c|c|c|c|c|c|c|}
\hline & \multicolumn{3}{|c|}{ Economic (Figure 5) } & \multicolumn{3}{|c|}{ Planning (Figure 6) } & \multicolumn{2}{|c|}{ Ecological (Figure 8) } & \multicolumn{2}{|c|}{ Physical (Figure 7) } \\
\hline $\begin{array}{c}\text { Plant } \\
\text { required } \\
\text { area in } \mathrm{km}^{2} \\
{[25]}\end{array}$ & $\begin{array}{c}\text { Wind } \\
\text { speed }(\mathrm{m} / \mathrm{s}) / \\
\text { density } \\
\text { potential [3] }\end{array}$ & $\begin{array}{c}\text { Buffer } \\
\text { distance/ } \\
\text { proximity } \\
\text { from } \\
\text { electricity } \\
\text { grid, } m \text { [3] }\end{array}$ & $\begin{array}{l}\text { Proximity/ } \\
\text { buffer to } \\
\text { roads \& } \\
\text { highways, } \\
\text { m [8] }\end{array}$ & $\begin{array}{c}\text { Buffer } \\
\text { distance } \\
\text { from } \\
\text { forests } \\
\text { \& parks, m }\end{array}$ & $\begin{array}{c}\text { Buffer } \\
\text { distance } \\
\text { from } \\
\text { airports, } \\
\text { m [8] }\end{array}$ & $\begin{array}{l}\text { Buffer } \\
\text { distance/ } \\
\text { proximity } \\
\text { from } \\
\text { residential, } \\
\text { m [8] }\end{array}$ & $\begin{array}{c}\text { Buffer } \\
\text { distance } \\
\text { from lakes, } \\
\mathrm{m}[8]\end{array}$ & $\begin{array}{c}\text { Buffer } \\
\text { distance } \\
\text { from rivers, } \\
\mathrm{m}[8]\end{array}$ & Slope, \% [8] & $\begin{array}{c}\text { Altitude, } \\
\text { m [3] }\end{array}$ \\
\hline$\geq 4$ & $>4.4$ & $\begin{array}{l}>250 \text { and } \\
<10,000\end{array}$ & $\begin{array}{l}>500 \text { and } \\
<10,000\end{array}$ & $>300$ & $>3500$ & $>2000$ & $>400$ & $>400$ & $<10$ & $<2000$ \\
\hline
\end{tabular}


A study of the daily and hourly profile of the wind speed would allow us to have better results. However, we do not have these data for Cameroon. This study was made with the average annual wind speed observed in Cameroon. It could be optimized by using the map of synthesis of the different seasons (high season and low season) as well as the daily and hourly profile. However, this study is the first of its kind in Cameroon, already allows us to obtain the places in the country where we could install the wind farms connected to the electricity grid. A study of other sources of energy such as solar, hydro, biomass, geothermal will be the perspectives of our work.

\section{Conclusions}

The GIS-based model for the selection of wind farm sites was developed and used to assess the relevance of wind farm locations in Cameroon taking into account economic/technical, environmental and social factors. The main contribution of this paper is to show that the Boolean process can be combined with geographic information systems to evaluate the best wind farm development site using the Cameroon case study. Nine criteria, namely wind speed, proximity to network lines, slope, proximity to cities and proximity to roads, were used in the economic/technical assessment. The constraint criteria (i.e. environmental and social factors) that are: protected areas, rivers and water bodies, airports were used to prepare the stress map. Based on these criteria, the total area of sites suitable for the development of wind farms amounted to approximately $10,344.424539 \mathrm{~km}^{2}$ over a total land area of $465,400 \mathrm{~km}^{2}$ in Cameroon. The North, Far North, Northwest, Southwest, West and Cameroon Littoral regions are viable for integrating wind power into the grid. Among these different regions, the regions of the Far North and North are best suited for the installation of a wind farm. We also recall that the exclusion of surfaces of less than $4 \mathrm{~km}^{2}$ reduces the favorable surface of $1252 \mathrm{~km}^{2}$. This criterion, although little used in the publications, is necessary and allows refining our results by proposing sites respecting the standards. The Central, Eastern and much of Southern Cameroon regions have proved unsuitable for the installation of wind farms for network integration purposes. The limitations of this study are that other factors such as cost of land and constraints such as the military base have not been taken into account due to the lack of map data. However, we recall that the Boolean method is a strict method compared to other methods of analysis, because the selected sites will certainly have a higher energy potential using the Boolean method. In addition, the comparison of the Boolean approach with other known approaches has not been made. A future study will compare the use of the multi-criteria decision method integrating an AHP analytical hierarchy process (an analytical hierarchy process allows appropriate weighting of the criteria based on their relative importance) involving expert stakeholders with the Boolean method in the GIS software environment to determine suitable locations for wind farm construction. The use of the multi-criteria decision method integrating an analytical hierarchy process will there- 
fore be the subject of our future work in order to refine the results obtained with the Boolean method. We note from our study that Cameroon does not have a strong wind potential. It would be interesting to evaluate the potential of other types of renewable energies such as solar, hydro, biomass, geothermal... in order to combine them with wind to optimize the performance of the parks electric.

We also recall that this work was done for wind farms connected to the electricity network hence the criterion near the power grid. In addition, a study of parks in remote areas and far from the electricity and road network could be considered in order to overcome the problems of access to electricity that rural population who do not have access to electricity encounter.

\section{Acknowledgements}

This work would never have been possible without the scholarship offered by the ARES for a six-month advanced training course in Geographic Information System (GIS) at the Institute of Management of Environment and Land Use Planning (IGEAT) at the Université Libre de Bruxelles (ULB) in Belgium. We thank our coordinator Maëlle VERCAUTEREN and our supervisor HUART Michel for this purpose.

\section{Conflicts of Interest}

The authors declare no conflicts of interest regarding the publication of this paper.

\section{References}

[1] Ayodele, T.R., Ogunjuyigbe, A.S.O., Odigie, O. and Munda, J.L. (2018) A MultiCriteria GIS Based Model for Wind Farm Site Selection Using Interval Type-2 Fuzzy Analytic Hierarchy Process: The Case Study of Nigeria. Applied Energy, 228, 1853 1869. https://doi.org/10.1016/j.apenergy.2018.07.051

[2] Baseer, M.A., Rehman, S., Meyer, J.P. and Alam, M.M. (2017) GIS-Based Site Suitability Analysis for Wind Farm Development in Saudi Arabia. Energy, 141, 1166 1176. https://doi.org/10.1016/j.energy.2017.10.016

[3] Ayodele, T.R., Ogunjuyigbe, A.S.O., Odigie, O. and Jimoh, A.A. (2018) On the Most Suitable Sites for Wind Farm Development in Nigeria. Data in Brief, 19, 29-41. https://doi.org/10.1016/j.dib.2018.04.144

[4] Siyal, S.H., Mörtberg, U., Mentis, D., Welsch, M., Babelon, I. and Howells, M. (2015) Wind Energy Assessment Considering Geographic and Environmental Restrictions in Sweden: A GIS-Based Approach. Energy, 83, 447-461. https://doi.org/10.1016/j.energy.2015.02.044

[5] Jangid, J., et al. (2016) Potential Zones Identification for Harvesting Wind Energy Resources in Desert Region of India-A Multi Criteria Evaluation Approach Using Remote Sensing and GIS. Renewable and Sustainable Energy Reviews, 65, 1-10. https://doi.org/10.1016/j.rser.2016.06.078

[6] Noorollahi, Y., Yousefi, H. and Mohammadi, M. (2016) Multi-Criteria Decision Support System for Wind Farm Site Selection Using GIS. Sustainable Energy Techno- 
logies and Assessments, 13, 38-50. https://doi.org/10.1016/j.seta.2015.11.007

[7] Watson, J.J.W. and Hudson, M.D. (2015) Regional Scale Wind Farm and Solar Farm Suitability Assessment Using GIS-Assisted Multi-Criteria Evaluation. Landscape and Urban Planning, 138, 20-31. https://doi.org/10.1016/j.landurbplan.2015.02.001

[8] Anwarzai, M.A. and Nagasaka, K. (2017) Utility-Scale Implementable Potential of Wind and Solar Energies for Afghanistan Using GIS Multi-Criteria Decision Analysis. Renewable and Sustainable Energy Reviews, 71, 150-160. https://doi.org/10.1016/j.rser.2016.12.048

[9] Mentis, D., Hermann, S., Howells, M., Welsch, M. and Siyal, S.H. (2015) Assessing the Technical Wind Energy Potential in Africa a GIS-Based Approach. Renewable Energy, 83, 110-125. https://doi.org/10.1016/j.renene.2015.03.072

[10] Villacreses, G., Gaona, G., Martínez-Gómez, J. and Jijón, D.J. (2017) Wind Farms Suitability Location Using Geographical Information System (GIS), Based on MultiCriteria Decision Making (MCDM) Methods: The Case of Continental Ecuador. Renewable Energy, 109, 275-286. https://doi.org/10.1016/j.renene.2017.03.041

[11] Atici, K.B., Simsek, A.B., Ulucan, A. and Tosun, M.U. (2015) A GIS-Based Multiple Criteria Decision Analysis Approach for Wind Power Plant Site Selection. Utilities Policy, 37, 86-96. https://doi.org/10.1016/j.jup.2015.06.001

[12] Gigović, L., Pamučar, D., Božanić, D. and Ljubojević, S. (2017) Application of the GIS-DANP-MABAC Multi-Criteria Model for Selecting the Location of Wind Farms: A Case Study of Vojvodina, Serbia. Renewable Energy, 103, 501-521. https://doi.org/10.1016/j.renene.2016.11.057

[13] Latinopoulos, D. and Kechagia, K. (2015) A GIS-Based Multi-Criteria Evaluation for Wind Farm Site Selection. A Regional Scale Application in Greece. Renewable Energy, 78, 550-560. https://doi.org/10.1016/j.renene.2015.01.041

[14] Al-Yahyai, S., Charabi, Y., Gastli, A. and Al-Badi, A. (2012) Wind Farm Land Suitability Indexing Using Multi-Criteria Analysis. Renewable Energy, 44, 80-87. https://doi.org/10.1016/j.renene.2012.01.004

[15] Sánchez-Lozano, J.M., García-Cascales, M.S. and Lamata, M.T. (2016) GIS-Based Onshore Wind farm Site Selection Using Fuzzy Multi-Criteria Decision Making Methods. Evaluating the Case of Southeastern Spain. Applied Energy, 171, 86-102. https://doi.org/10.1016/j.apenergy.2016.03.030

[16] https://gadm.org

[17] http://www.worldclim.org

[18] http://www.worldpop.org.uk/data

[19] http://databank.banquemondiale.org/data/reports.aspx? source $=2 \&$ country $=\mathrm{CMR}$

[20] https://www.openstreetmap.org/\#map=6/7.402/12.343

[21] USGS EROS Archive-Digital Elevation-Shuttle Radar Topography Mission (SRTM) Non-Void Filled.

https://www.usgs.gov/centers/eros/science/usgs-eros-archive-digital-elevation-shutt le-radar-topography-mission-srtm-non?qt-science center objects=0\#qt-science ce nter objects

[22] https://www.adcsa.aero/aeroports

[23] Church, R.L. (2002) Geographical Information Systems and Location Science. Computers \& Operations Research, 29, 541-562.

http://ratt.ced.berkeley.edu/readings/GIS readings/Church 2002.pdf https://doi.org/10.1016/S0305-0548(99)00104-5 
[24] Falconer, L., Hunter, D., Telfer, T.C. and Ross, L.G. (2013) Land Use Policy Visual, Seascape and Landscape Analysis to Support Coastal Aquaculture Site Selection. Land Use Policy, 34, 1-10. https://doi.org/10.1016/j.landusepol.2013.02.002

[25] Sánchez-lozano, J.M., Teruel-solano, J., Soto-elvira, P.L. and García-cascales, M.S. (2013) Geographical Information Systems (GIS) and Multi-Criteria Decision Making (MCDM) Methods for the Evaluation of Solar Farms Locations: Case Study in South-Eastern Spain. Renewable and Sustainable Energy Reviews, 24, 544-556.

https://doi.org/10.1016/j.rser.2013.03.019 